\title{
Studies on the Mode of Action of the Streptogramin Antibiotics
}

\author{
By D. VAZQUEZ \\ Sub-Department of Chemical Microbiology, Department of Biochemistry, \\ Tennis Court Road, Cambridge
}

(Received 20 July 1965)

\begin{abstract}
SUMMARY
Streptogramin is a complex antibiotic containing two components, streptogramin A and streptogramin B. The individual components are bacteriostatic whereas the mixture is bactericidal. At growth-limiting concentrations streptogramin $\mathbf{A}$ and the streptogramin complex inhibit Staphylococcus aureus by blocking protein synthesis but not nucleic acid and cell wall synthesis. Protein, nucleic acid and cell wall synthesis were all reduced in the presence of streptogramin $B$.

Streptogramin A, but not streptogramin B, inhibits the binding of radioactive chloramphenicol to bacterial ribosomes. However, streptogramin $B$ enhances this effect of streptogramin $A$ in a cell-free system containing both bacterial soluble fraction and ribosomes. The results suggest that streptogramin A inhibits protein synthesis by bacteria at the ribosome level, and that this effect is enhanced by streptogramin $B$.
\end{abstract}

\section{INTRODUCTION}

The antibiotic streptogramin was first obtained from culture filtrates of a species of Streptomyces, now classified as Streptomyces graminofaciens (Charney et al. 1953). Other antibiotics closely related to streptogramin have been described, for example, virgimycin or staphylomycin (De Somer \& Van Dijck, 1955), E 129 or ostreogrycin (Garrod \& Waterworth, 1956; Ball et al. 1958), synergistin or PA 114 (Celmer \& Sobin, 1955/1956), mikamycin (Arai et al. 1956), pristinamycin or pyostacin (Benazet et al. 1962) and vernamycin (Bodanszky \& Ondetti, 1963). All these antibiotics are mixtures of two or more different active compounds, and there are numerous reports on the isolation and properties of the individual components from PA 114, staphylomycin, ostreogrycin, mikamycin and vernamycin. All these complex antibiotics consist of at least two components belonging to two major groups, $\mathbf{A}$ and $\mathbf{B}$. The antibiotics in group $\mathbf{A}$ show a marked synergism with those in group $B$ in their activity against Gram-positive bacteria and consequently the complex antibiotics of the streptogramin family have a markedly higher activity than the individual components. The classification of the antibiotics of the streptogramin family has been reviewed by Lester Smith (1963).

The antibiotics in group $A$ are mainly active against Gram-positive cocci and the antibiotics in group B against Gram-positive bacilli. Although there is a strong synergism between the antibiotics of groups $\mathbf{A}$ and $\mathbf{B}$ in their antibacterial effect against Gram-positive bacteria in general, there is no such effect on Gram-negative organisms; consequently, the antibiotic complexes are effective mainly against Gram-positive bacteria. 
This work describes investigations of the mode of action of streptogramin and its components in an attempt to clarify the mechanism of the remarkable synergism shown by mixtures of the individual antibiotics. Preliminary reports of this work have been published (Vazquez, 1962, 1963a, 1964b).

\section{METHODS}

Organisms and growth conditions. The organisms used in this work were Staphylococcus aureus strain Duncan, Bacillus megaterium strain KM (NCIB 9521) and Escherichia coli, strain B. Staphylococcus aureus was grown overnight at $37^{\circ}$ in medium $\mathbf{A}$ of Gale (1947). Next morning the culture was diluted 10 times with fresh medium and incubation continued. For studies of synthesis of cellular constituents or isotope incorporation, $S$. aureus was resuspended in the defined medium of Gale \& Folkes $(1953 a)$ containing glucose, amino acids, purines, pyrimidines and the buffered salt solution of Gale (1947). Bacillus megaterium and $\boldsymbol{E}$. coli were grown overnight aerobically in CG medium containing $0.03 \%$ (w/v) glucose (McQuillen \& Roberts 1954) at $30^{\circ}$ and $37^{\circ}$ respectively. In the morning, excess glucose was added and incubation continued. Growth of bacteria was followed by measuring the optical density as previously described (Vazquez, 1965a).

Viable counts. Viable counts were made in triplicate on medium $A+2 \%(w / v)$ agar using the method described by Miles \& Misra (1938) after serial dilution of the bacteria in saline.

\section{Synthesis of cellular constituents}

(a) Net synthesis. Suspensions of Staphylococcus aureus at an initial concentration equivalar $1 \mathrm{mg}$. dry wt./ml. were incubated statically at $37^{\circ}$ in the defined medium. Samples of $3 \mathrm{ml}$. were taken at intervals and cooled rapidly. Bacteria were harvested by centrifugation and washed with the buffered salt solution. The bacterial pellet was extracted twice with $2 \mathrm{ml}$. of $0.2 \mathrm{~N}$-perchloric acid at $4^{\circ}$ for $60 \mathrm{~min}$. and the supernatant fluids from these extractions combined. This constituted the pool fraction. The nucleic acids were extracted from the pellet with $3 \mathrm{ml} .0 .5 \mathrm{~N}-$ perchloric acid at $70^{\circ}$ for $20 \mathrm{~min}$. (three extractions were sufficient). The nucleic acids were estimated by measuring the absorption at $260 \mathrm{~m} \mu$ in a Unicam SP 500 spectrophotometer. A solution of $100 \mu \mathrm{g}$. nucleic acid $/ \mathrm{ml}$. was assumed to have an absorption of 2.8 (Gale \& Folkes, $1953 a$ ). The DNA in the $0.5 \mathrm{~N}$-perchloric extracts was estimated by the diphenylamine method of Burton (1956).

The residual pellet was taken up in $\mathrm{N}-\mathrm{NaOH}$ and protein in this solution was estimated by the method of Lowry et al. (1951).

(b) Isotope incorporation. Suspensions of Staphylococcus aureus at an initial cell concentration equivalar $1 \mathrm{mg}$. dry wt. $/ \mathrm{ml}$. were incubated at $37^{\circ}$ statically in the defined medium to which a ${ }^{14} \mathrm{C}$-labelled compound had been added. Samples of $1 \mathrm{ml}$. were taken at intervals and cooled rapidly. The bacteria were harvested by centrifugation and washed with $5 \mathrm{ml}$. of the buffered salt solution. The bacterial pellet was extracted with $3 \mathrm{ml} .5 \%(\mathrm{w} / \mathrm{v})$ trichloroacetic acid for $1 \mathrm{hr}$ at $4^{\circ}$; nucleic acids were extracted from the pellet with $3 \mathrm{ml}$. of $5 \%(\mathrm{w} / \mathrm{v})$ trichloroacetic acid at $90^{\circ}$ for $15 \mathrm{~min}$. The insoluble material remaining after this extraction was washed once with $2 \mathrm{ml}$. 0.01 $\mathrm{M}-\mathrm{NH}_{4} \mathrm{HCO}_{3}$, resuspended in $2 \mathrm{ml}$. of this solution, and digested with $2 \mathrm{mg}$. trypsin to separate the protein and the cell-wall fractions (Hancock \& Park, 1958). 
Samples of every fraction were transferred to aluminium planchets and radioactivity determined as previously described (Vazquez, 1965b).

Uptake of chloramphenicol. The effect of the streptogramin antibiotics on the uptake of ${ }^{14} \mathrm{C}$-labelled chloramphenicol (methylene ${ }^{14} \mathrm{C} ; 9.90 \mu \mathrm{C} / \mu \mathrm{mol} ;\left[{ }^{14} \mathrm{C}\right] \mathrm{CAP}$ ) by Staphylococcus aureus suspended in medium $\mathbf{A}$ was studied as described by Vazquez $(1965 b)$ for Bacillus megaterium. The non-radioactive antibiotics were mixed in the tubes with $\left.{ }^{[14} \mathrm{C}\right] \mathrm{CAP}$ prior to the addition of bacterial suspensions.

Preparation of bacterial cell sap and ribosomes. Suspensions of Staphylococcus aureus (100 mg. dry wt./ml.) in the buffered salt solution were disrupted in a Mullard ultrasonic disintegrator (model SL 82) for $10 \mathrm{~min}$. Broken cell walls and membranes were separated by centrifugation at $40,000 \mathrm{~g}$ for $20 \mathrm{~min}$. and discarded. The supernatant cell sap was diluted with buffered salt solution when required. The buffered salt solution contained $0.002 \mathrm{M}-\mathrm{Mg}^{2+}$ and under these conditions the ribosomes were split into $30 \mathrm{~S}$ and $50 \mathrm{~S}$ ribosomal subunits. Ribosomes from Bacillus megaterium and Escherichia coli were obtained as previously described (Vazquez, 1965a). These ribosomes were resuspended in $0.01 \mathrm{M}$-tris $+\mathrm{HCl}$ buffer, pH $\mathbf{7 \cdot 4}$, containing $0 \cdot 2 \mathrm{M}-\mathrm{K}^{+}$.

$\left[{ }^{14} \mathrm{C}\right] \mathrm{CAP}$ binding to ribosomes. The effect of the streptogramin antibiotics on $\left[{ }^{14} \mathrm{C}\right] \mathrm{CAP}$ binding to Staphylococcus aureus ribosomes was studied without separating the ribosomes from the bacterial 'soluble fraction' using bacterial cell sap. Suspensions of Bacillus megaterium ribosomes in $0 \cdot 01 \mathrm{M}$-tris- $\mathrm{HCl}$ buffer, $\mathrm{pH} 7 \cdot 4$, containing $0.2 \mathrm{M}-\mathrm{K}^{+}$were also used for binding experiments. The experiments were carried out as described by Vazquez $(\mathbf{1 9 6 5} b)$. The non-radioactive antibiotics were mixed in the tubes with $\left.{ }^{14} \mathrm{C}\right] \mathrm{CAP}$ before adding of ribosome suspensions. $\boldsymbol{B}$. megaterium and $S$. aureus ribosomes were harvested by centrifugation at $150,000 \mathrm{~g}$ for $100 \mathrm{~min}$. and $150 \mathrm{~min}$., respectively.

Antibiotics. Streptogramin, PA 114-A-1 and PA 114-B-1 were kindly supplied by Dr H. B. Woodruff. The two major components of streptogramin (streptogramin A and streptogramin B) were separated and purified following the methods described by Vanderhaeghe, Van Dijck, Parmentier \& De Somer (1957) for the separation of the components of staphylomycin. Streptogramin A was further purified by the method described by Sarin (1962) for the purification of ostreogrycin A. The ultraviolet and infrared spectra of the streptogramins $A$ and $B$ were determined and compared with those of PA 114-A-1 and PA 114-B-1. There were no significant differences between streptogramin A and PA 114-A-1, or streptogramin B and PA 114-B-1. The chemical structures of the individual components of the streptogramin complex have not been published, but Dr Woodruff and Dr Lester Smith (personal communications) have suggested that streptogramins $\mathbf{A}$ and $\mathbf{B}$ are identical with PA 114-A-1 (synonym, ostreogrycin A) and PA 114-B-1 (synonym, ostreogrycin $B)$, respectively.

PA 114-A-1 and PA 114-B-1 were used in this work, and will be referred to as component $\mathbf{A}$ and component $\mathbf{B}$ of streptogramin. In many experiments the individual components isolated from streptogramin were also used to confirm results obtained.

The sources of other antibiotics used in this work are given by Vazquez (1965b).

Isotopically labelled compounds were obtained from the Radiochemical Centre, Amersham, Buckinghamshire. 


\section{RESULTS}

Effect on the viability of Staphylococcus aureus. The limiting growth-inhibitory concentrations for Staphylococcus aureus of streptogramin, component $\mathbf{A}$ and component B were respectively, $0 \cdot 6,6$, and $10 \mu \mathrm{g}$. $/ \mathrm{ml}$. Streptogramin was bactericidal whereas the individual components $\mathbf{A}$ and $\mathbf{B}$ were bacteriostatic, even when tested at three times the minimum growth-inhibitory concentrations. The effect of mixtures of component A with other antibiotics on the viability of $S$. aureus was studied with the results shown in Table 1 . Bactericidal effects were found when component $\mathbf{A}$ was mixed with either viridogrisein (Garcia-Mendoza, 1965) or component B and to a lesser extent when mixed with aureomycin or terramycin. On the other hand, component A prevented the lethal effect of streptomycin but not that of echinomycin.

Table 1. The effect of component $A$ with other antibiotics on the viability of Staphylococcus aureus

\begin{tabular}{|c|c|c|c|}
\hline \multirow[b]{2}{*}{ Antibiotics } & \multicolumn{3}{|c|}{ Colony count } \\
\hline & $0 \mathrm{~min}$. & $75 \mathrm{~min}$. & $150 \mathrm{~min}$. \\
\hline None & & $\left(8.0 \times 10^{7}\right.$ & $1.5 \times 10^{8}$ \\
\hline $\begin{array}{l}\text { Component A ('A') } \\
\text { 'A' + Component B }\end{array}$ & & $\begin{array}{l}3.3 \times 10^{7} \\
1.2 \times 10^{5}\end{array}$ & $\begin{array}{r}3.5 \times 10^{7} \\
<10^{5}\end{array}$ \\
\hline $\begin{array}{l}\text { Viridogrisein } \\
\text { 'A' + Viridogrisein }\end{array}$ & & $\begin{array}{l}3.5 \times 10^{7} \\
1.0 \times 10^{5}\end{array}$ & $\begin{array}{r}4.5 \times 10^{7} \\
<10^{5}\end{array}$ \\
\hline $\begin{array}{l}\text { Aureomycin } \\
\text { 'A'+Aureomycin }\end{array}$ & & $\begin{array}{l}2.5 \times 10^{7} \\
9 \cdot 2 \times 10^{8}\end{array}$ & $\begin{array}{l}2 \cdot 1 \times 10^{7} \\
3 \cdot 0 \times 10^{6}\end{array}$ \\
\hline $\begin{array}{l}\text { Terramycin } \\
\text { 'A'+Terramycin }\end{array}$ & $3.0 \times 10^{7}$ & $\left\{\begin{array}{l}3.0 \times 10^{7} \\
1.2 \times 10^{7}\end{array}\right.$ & $\begin{array}{l}2.8 \times 10^{7} \\
8.0 \times 10^{6}\end{array}$ \\
\hline $\begin{array}{l}\text { Chloramphenicol } \\
\text { 'A'+Chloramphenicol }\end{array}$ & & $\begin{array}{l}5.4 \times 10^{7} \\
3.4 \times 10^{7}\end{array}$ & $\begin{array}{l}9.0 \times 10^{7} \\
3.5 \times 10^{7}\end{array}$ \\
\hline $\begin{array}{l}\text { Streptomycin } \\
\text { 'A'+Streptomycin }\end{array}$ & & $\begin{array}{l}8.0 \times 10^{8} \\
3.0 \times 10^{7}\end{array}$ & $\begin{array}{l}2 \cdot 5 \times 10^{6} \\
3 \cdot 1 \times 10^{7}\end{array}$ \\
\hline $\begin{array}{l}\text { Echinomycin } \\
\text { 'A'+Echinomycin }\end{array}$ & & $\begin{array}{l}7 \cdot 5 \times 10^{6} \\
7 \cdot 2 \times 10^{8}\end{array}$ & $\begin{array}{l}2.5 \times 10^{6} \\
3.0 \times 10^{6}\end{array}$ \\
\hline
\end{tabular}

Staphylococcus aureus (8.0 $\times 10^{7}$ bacteria $/ \mathrm{ml}$.) was incubated at $37^{\circ}$ for $150 \mathrm{~min}$. in medium $\mathbf{A}$. Antibiotics were added simultaneously (final concentrations $2 \times 10^{-6} \mathrm{M}$ ), at the beginning of the incubation period. The colony count was determined by the method of Miles \& Misra (1988).

Chloramphenicol, aureomycin, terramycin, erythromycin and carbomycin prevent the bactericidal action of penicillin and streptomycin on many bacteria (Jawetz, Gunnison, Bruff \& Coleman, 1952; Coleman, Gunnison \& Jawetz, 1953; Anand \& Davis, 1960; Hurwitz \& Rosano, 1962). A similar protective effect of chloramphenicol was found when it was added with streptogramin to an exponentially growing culture of Staphylococcus aureus. The protective effect of chloramphenicol occurred to the same extent when it was added to the bacterial culture before, or at the same time as, streptogramin, and to some extent when added after streptogramin (Table 2).

Penicillin and streptomycin are bactericidal only when the bacteria are growing (Kirby \& Burnell, 1954; Prestidge \& Pardee, 1957; Anand \& Davis, 1960), and it was thought that chloramphenicol might protect by preventing growth. However, 
this may not be the complete explanation in the case of streptogramin, as chloramphenicol at $3 \mu \mathrm{g} . / \mathrm{ml}$. inhibited the growth of Staphylococcus aureus by only $60 \%$ but still prevented the bactericidal effect of streptogramin (Fig. 1).

Erythromycin, puromycin, aureomycin and terramycin are bacteriostatic and inhibit growth of Staphylococcus aureus at concentrations of 1, 50, 1 and $1 \mu \mathrm{g} . / \mathrm{ml}$. respectively. At growth inhibitory concentrations erythromycin also prevented the bactericidal effect of streptogramin, and puromycin had no such effect, while aureomycin and terramycin increased its bactericidal effect. When growth of $S$. aureus was prevented by using a defined medium with glutamic acid omitted, the bactericidal effect of streptogramin was not significantly decreased. These findings suggested that streptogramin can kill $S$. aureus, even when growth is lessened, and that the effect of chloramphenicol and erythromycin in preventing killing by streptogramin cannot be explained simply by their effect in inhibiting bacterial growth.

Table 2. The effect of time of addition of chloramphenicol on the bactericidal action of streptogramin

\begin{tabular}{|c|c|c|c|c|c|c|}
\hline \multicolumn{5}{|c|}{ Time of addition of antibiotics ( $\mathrm{min}$.) } & \multirow{2}{*}{$\begin{array}{l}\text { Colony count } \\
\text { after } 90 \text { min. } \\
\text { incubation }\end{array}$} & \multirow{2}{*}{$\begin{array}{c}\% \text { Decrease } \\
\text { in colony } \\
\text { count }\end{array}$} \\
\hline o & 1 & 3 & 5 & 10 & & \\
\hline - & - & - & - & - & $6.3 \times 10^{6}$ & - \\
\hline CAP & - & - & - & - & $2.7 \times 10^{6}$ & - \\
\hline $\mathbf{S}$ & - & - & - & - & $8 \cdot 1 \times 10^{4}$ & 96 \\
\hline $\mathbf{C A P}+\mathrm{S}$ & - & - & - & - & $2.5 \times 10^{6}$ & - \\
\hline $\mathrm{S}$ & CAP & - & - & - & $2.2 \times 10^{6}$ & 12 \\
\hline $\mathbf{s}$ & - & CAP & - & - & $1.5 \times 10^{6}$ & 40 \\
\hline $\mathbf{S}$ & - & - & CAP & - & $9 \cdot 0 \times 10^{5}$ & 64 \\
\hline $\mathbf{S}$ & - & - & - & CAP & $6.0 \times 10^{5}$ & 76 \\
\hline CAP & $\mathbf{s}$ & - & - & - & $2.6 \times 10^{6}$ & - \\
\hline CAP & - & $\mathbf{S}$ & - & - & $2.2 \times 10^{6}$ & 12 \\
\hline CAP & - & - & $\mathbf{S}$ & - & $2.2 \times 10^{6}$ & 12 \\
\hline CAP & - & - & - & $\mathbf{s}$ & $2.4 \times 10^{6}$ & 6 \\
\hline
\end{tabular}

Staphylococcus aureus $\left(2.5 \times 10^{6} \mathrm{bacteria} / \mathrm{ml}\right.$.) was incubated at $37^{\circ}$ in medium $\mathrm{A}$ for $90 \mathrm{~min}$. Chloramphenicol at $10 \mu \mathrm{g} . / \mathrm{ml}$. (CAP) and streptogramin at $0.6 \mu \mathrm{g} . / \mathrm{ml}$. (S) were added at the times shown in the Table. The colony count was determined by the method of Miles \& Misra (1938).

Respiration and fermentation. Streptogramin and the individual components $\mathbf{A}$ and $B$ at concentrations of up to $60 \mu \mathrm{g} . / \mathrm{ml}$., had no effect on endogenous respiration, oxidation of ethanol or glucose, or anaerobic fermentation of glucose when added to washed suspensions of Staphylococcus aureus in the Warburg vessels. The studies were carried out using the manometric techniques described by Umbreit, Burris \& Stauffer (1949).

Synthesis of cellular constituents. The effect of component A on net synthesis and on the incorporation of radioactive isotopes into the different cell fractions is shown in Tables 3 and 4. These results indicate that the antibiotic inhibits bacterial growth by blocking protein synthesis. The inhibitory effect of the antibiotic on the incorporation of [U-14 $\mathrm{C}]$ glycine into the protein fraction was detected within $30 \mathrm{sec}$. of addition of the antibiotic (Fig. 2). Similar results were obtained with $\mathrm{L}-\left[\mathrm{U}^{-14} \mathrm{C}\right]-$ lysine. The increased rate of glutamic acid accumulation in the pool in the presence 
of component $\mathbf{A}$ was probably due to the amino acid not being incorporated in the protein fraction, and has been observed in the presence of other inhibitors of protein synthesis like chloramphenicol (Hancock, 1960). The increased nucleic acid content in the presence of component $A$ was due to an increase of RNA accumulation; the synthesis of DNA was unaffected. An increase in the rate of accumulation of RNA has also been observed in bacteria treated with chloramphenicol (see Gale, 1963).

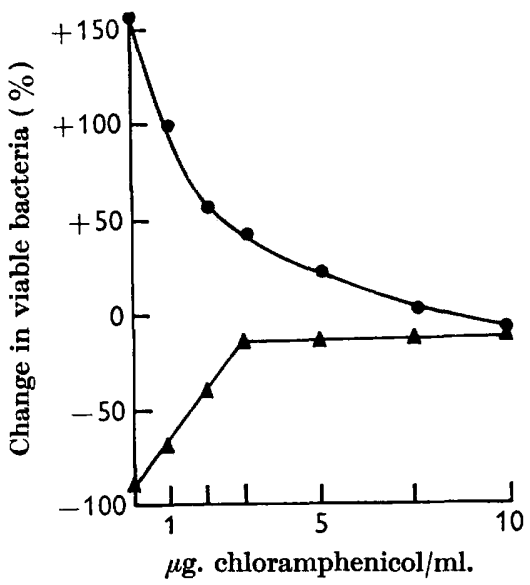

Fig. 1.

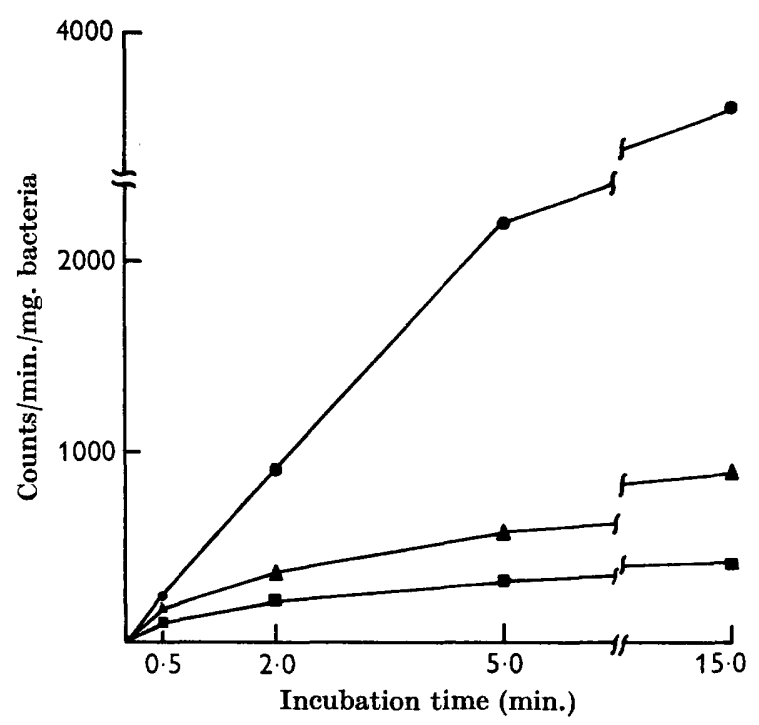

Fig. 2.

Fig. 1. The effect of chloramphenicol on the bactericidal action of streptogramin. Suspensions of Staphylococcus aureus $\left(7 \times 10^{5}\right.$ bacteria $/ \mathrm{ml}$.) were incubated in medium A at $37^{\circ}$ for $90 \mathrm{~min}$. and viable bacteria were counted at the beginning and at the end of the incubation period by the method of Miles \& Misra (1938). - - No streptogramin added; $-\Delta-\Delta-, 0 \cdot 6 \mu \mathrm{g}$. streptogramin $/ \mathrm{ml}$.

Fig. 2. The effect of component $A$ on the incorporation of $\left[\mathrm{U}-{ }^{14} \mathrm{C}\right]$ glycine into the protein fraction of Staphylococcus aureus. Suspensions of $1 \mathrm{mg}$. $S$. aureus $/ \mathrm{ml}$. were incubated at $37^{\circ}$ for $15 \mathrm{~min}$. in the defined medium without adenine or guanine and supplemented with $\left[\mathrm{U}-{ }^{14} \mathrm{C}\right] \mathrm{glycine}(36 \mu \mathrm{g} . / \mathrm{ml} . ; 0.4 \mu \mathrm{c} . / \mathrm{ml}$.). Samples were taken at intervals and fractionated by the method of Hancock \& Park (1958). - _-_- Control; $\Delta-\Delta-, 6 \mu \mathrm{g}$. component A/ml.; $-\square-\square, 20 \mu \mathrm{g}$. component $\mathrm{A} / \mathrm{ml}$.

Similar experiments with component B suggest that it has a complex effect on Staphylococcus aureus (Tables 3 and 4). Protein, nucleic acid, and cell-wall synthesis were all reduced. However, the incorporation of glycine into the protein fraction was affected by component $B$ within 30 sec., whereas the effect on nucleic acid and cell wall fractions was not established until after 1-2 min. Similar results were obtained for the incorporation of $\mathrm{L}-\left[\mathrm{U}-{ }^{14} \mathrm{C}\right] \mathrm{lysine}$.

These results are very similar to those reported by Garcia-Mendoza (1965) for the effect of viridogrisein on Staphylococcus aureus. Viridogrisein is included in group $B$ of the streptogramin family of antibiotics and is more active than the other members of this group in inhibiting bacterial growth and protein synthesis. The effects of equal concentrations of viridogrisein and component $B$ on nucleic acid and cell-wall synthesis were found to be very similar. 
Effect of the streptogramin complex. The effect of the streptogramin complex at limiting growth-inhibitory concentrations on the net synthesis and incorporation of radioactive isotopes in the different cell fractions is shown in Tables 3 and 4, and resembles those obtained with component $A$ (at $10 \times$ concentration). The main

Table 3. The effect of the streptogramin antibiotics on synthesis of cellular constituents

\begin{tabular}{|c|c|c|c|c|}
\hline \multirow[b]{2}{*}{ Antibiotic } & \multirow[b]{2}{*}{$\mu \mathrm{g} \cdot / \mathrm{ml}$} & \multicolumn{2}{|c|}{$\overbrace{\begin{array}{c}260 \mathrm{~m} \mu \text { absorbing } \\
\text { material }\end{array}}^{\text {Net synthesis of control }}$} & \multirow{2}{*}{$\begin{array}{l}\text { Protein } \\
\text { estimated } \\
\text { in the } \\
\text { fraction } \\
\text { insoluble } \\
\text { in hot } \\
\text { perchloric } \\
\text { acid }\end{array}$} \\
\hline & & Pool & $\begin{array}{c}\text { NA* } \\
\text { fraction }\end{array}$ & \\
\hline Component A & $\begin{array}{r}6 \cdot 0 \\
20 \cdot 0\end{array}$ & $\begin{array}{l}100 \\
100\end{array}$ & $\begin{array}{l}173 \\
158\end{array}$ & $\begin{array}{l}32 \\
16\end{array}$ \\
\hline Component B & $\begin{array}{l}10 \cdot 0 \\
30 \cdot 0\end{array}$ & $\begin{array}{l}87 \\
80\end{array}$ & $\begin{array}{l}61 \\
57\end{array}$ & $\begin{array}{l}56 \\
42\end{array}$ \\
\hline Streptogramin & $\begin{array}{l}0 \cdot 6 \\
2 \cdot 0\end{array}$ & $\begin{array}{l}100 \\
100\end{array}$ & $\begin{array}{l}174 \\
163\end{array}$ & $\begin{array}{l}38 \\
15\end{array}$ \\
\hline
\end{tabular}

NA*: total nucleic acid. Suspensions of $1 \mathrm{mg}$. Staphylococcus aureus $/ \mathrm{ml}$. were incubated at $37^{\circ}$ for $15 \mathrm{~min}$. in the defined medium. Samples were taken at the beginning and at the end of the incubation period, fractionated by perchloric acid treatment, and protein estimated in the hot perchloric acid-insoluble fraction.

Table 4. The effect of the streptogramin antibiotics on synthesis
of cellular constituents Incorporation of radioactive compounds

\begin{tabular}{|c|c|c|c|c|c|c|}
\hline \multirow[b]{2}{*}{ Antibiotic } & \multirow[b]{2}{*}{$\mu \mathrm{g} \cdot / \mathrm{ml}$} & \multirow[b]{2}{*}{ Radioactive compound } & \multicolumn{4}{|c|}{$\%$ control incorporation } \\
\hline & & & Pool & NA* & Protein & Wall \\
\hline \multirow[t]{6}{*}{ Component A } & $6 \cdot 0$ & {$\left[\mathrm{U}-{ }^{14} \mathrm{C}\right]$ Glycine } & 100 & 100 & 26 & 100 \\
\hline & $20 \cdot 0$ & L- J & 100 & 100 & 12 & 100 \\
\hline & $6 \cdot 0$ & L- $\left[\mathrm{U}^{14} \mathrm{C}\right]$ Glutamic acid & 120 & 100 & 27 & 100 \\
\hline & $20 \cdot 0$ & & 128 & 100 & 11 & 100 \\
\hline & $6 \cdot 0$ & {$\left[8-{ }^{14} \mathrm{C}\right]$ Adenine } & 126 & 204 & - & - \\
\hline & $20 \cdot 0$ & & 121 & 189 & - & - \\
\hline \multirow[t]{6}{*}{ Component B } & $10 \cdot 0$ & {$\left[\mathbf{U}^{-14} \mathbf{C}\right]$ Glycine } & 77 & 59 & 54 & 57 \\
\hline & $30 \cdot 0$ & & 73 & 49 & 43 & 46 \\
\hline & $10 \cdot 0$ & $\mathrm{~L}-\left[\mathrm{U}-{ }^{14} \mathrm{C}\right]$ Glutamic acid & 83 & $\mathbf{5 7}$ & 52 & 58 \\
\hline & $30 \cdot 0$ & & 76 & 46 & 40 & 48 \\
\hline & $10 \cdot 0$ & [8-14C]Adenine & 74 & 61 & - & - \\
\hline & $30 \cdot 0$ & & 69 & 58 & - & - \\
\hline \multirow[t]{6}{*}{ Streptogramin } & $0 \cdot 6$ & [U-14C]Glycine & 100 & 100 & 34 & 100 \\
\hline & $\mathbf{2 \cdot 0}$ & & 100 & 100 & 11 & 100 \\
\hline & $0 \cdot 6$ & L-[U-14 C)Glutamic acid & 118 & 100 & 35 & 100 \\
\hline & $\mathbf{2} \cdot 0$ & & 127 & 100 & 10 & 100 \\
\hline & $0 \cdot 6$ & [8-14C]Adenine & 130 & 206 & - & - \\
\hline & $2 \cdot 0$ & & 120 & 176 & - & - \\
\hline
\end{tabular}

*NA: total nucleic acid. [U-14 C]Glycine added $0 \cdot 4 \mu \mathrm{C}$. $/ \mathrm{ml}$; $36 \mu \mathrm{g} . / \mathrm{ml}$. L-[U- $\left.{ }^{14} \mathrm{C}\right] \mathrm{Glutamic}$ acid added $0.1 \mu \mathrm{C} . / \mathrm{ml}$; $100 \mu \mathrm{g} . / \mathrm{ml}$. [8- $\left.{ }^{14} \mathrm{C}\right]$ Adenine added $0.05 \mu \mathrm{C} . / \mathrm{ml}$.; $10 \mu \mathrm{g} . / \mathrm{ml}$.

Suspensions of $1 \mathrm{mg}$. Staphylococcus aureus $/ \mathrm{ml}$. were incubated at $37^{\circ}$ for $15 \mathrm{~min}$. in the defined medium supplemented with the required radioactive compound. Samples were taken at the end of the incubation period, fractionated by the method of Hancock \& Park (1958), and the radio. activity in the fractions determined. 
difference is that component $\mathbf{A}$ had an immediate effect on protein synthesis, whereas a lag of about $2 \mathrm{~min}$. was observed before the synergistic mixture exerts its effect.

Gale \& Folkes $(1953 a)$ showed that the action of chloramphenicol on bacterial protein is reversible; synthesis begins again immediately the antibiotic is removed. A comparison was made of the inhibitory effects of chloramphenicol and streptogramin on net protein synthesis as measured by increase in the perchloric acidinsoluble fraction and their reversal in Staphylococcus aureus. The inhibitory effect of streptogramin was not readily reversible, and removal of the antibiotic was followed by only a slight increase in the rate of protein synthesis.

The effect of a mixture of chloramphenicol and streptogramin on $\mathrm{L}$-[U-14 C]glutamic acid incorporation into the protein fraction was studied, and showed that chloramphenicol at a concentration which prevented the lethal effect of streptogramin did not also block its inhibitory action on protein synthesis (Table 5).

Results similar to those found with streptogramin were obtained when an equivalent mixture of component $\mathrm{A}(\mathbf{8 0} \%)$ and $\mathrm{B}(20 \%)$ was used. (Fig. 3).

Table 5. Incorporation of ${ }^{14} \mathrm{C}$-labelled glutamic acid into protein. The effect of streptogramin with chloramphenicol

$\begin{array}{lc} & \begin{array}{c}\text { Bacteria } \\ \text { (counts/ } \\ \text { min./mg.) }\end{array} \\ \text { Control } & 1135 \\ \text { +CAP (3.5 } \mu \mathrm{g} . / \mathrm{ml} .) & \mathbf{4 8 5} \\ \text { + Streptogramin (0.9 } \mu \mathrm{g} . / \mathrm{ml} .) & 161 \\ \text { + CAP (3.5 } \mu \mathrm{g} . / \mathrm{ml} .)+ \text { Streptogramin }(0.9 \mu \mathrm{g} . / \mathrm{ml} .) & 150\end{array}$

Suspensions of $1 \mathrm{mg}$. Staphylococcus aureus $/ \mathrm{ml}$. were incubated at $37^{\circ}$ for $30 \mathrm{~min}$. in the defined medium without adenine nor guanine in the presence of ${ }^{14} \mathrm{C}$-labelled glutamic acid $0 \cdot 1 \mu \mathrm{C}$. $/ \mathrm{ml}$.; $100 \mu \mathrm{g} . / \mathrm{ml}$. Samples were taken and fractionated by the method of Hancock \& Park (1958).

Effect of the streptogramin antibiotics on the binding of chloramphenicol. Studies of the uptake of antibiotics by bacteria and their binding to different structures or components within the cell have been very helpful in elucidating their initial site of action.

As radioactive components $A$ and $B$ were not available, the uptake and binding of these antibiotics could not be studied directly. However, the results described above showed that component $\mathbf{A}$ had an overall effect resembling that of chloramphenicol, and it was thought that component $\mathbf{A}$ and chloramphenicol might compete for the same binding site(s) in sensitive bacteria. The binding of ${ }^{14} \mathrm{C}$-labelled chloramphenicol $\left.{ }^{[14} \mathrm{C}\right] \mathrm{CAP}$ has been used to test this hypothesis. Component A significantly reduced the uptake of $\left[{ }^{14} \mathrm{C}\right] \mathrm{CAP}$ by Staphylococcus aureus and the effect was somewhat enhanced by component B (Table 6). Component B also reduced

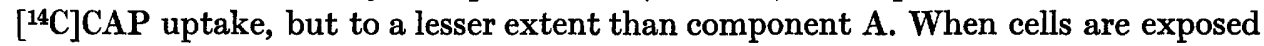
to $\left[{ }^{14} \mathrm{C}\right] \mathrm{CAP}$ and then broken and fractionated in the centrifuge, all the radioactivity is associated with the ribosomal and soluble fraction (Vazquez, 1963b).

The effect on the binding of chloramphenicol by ribosome preparations was next studied. In a cell-free system consisting of a mixture of ribosome subunits (30 $\mathrm{S}$ and $50 \mathrm{~S}$ ) and soluble fraction in the buffered salt solution, the ribosome bound 


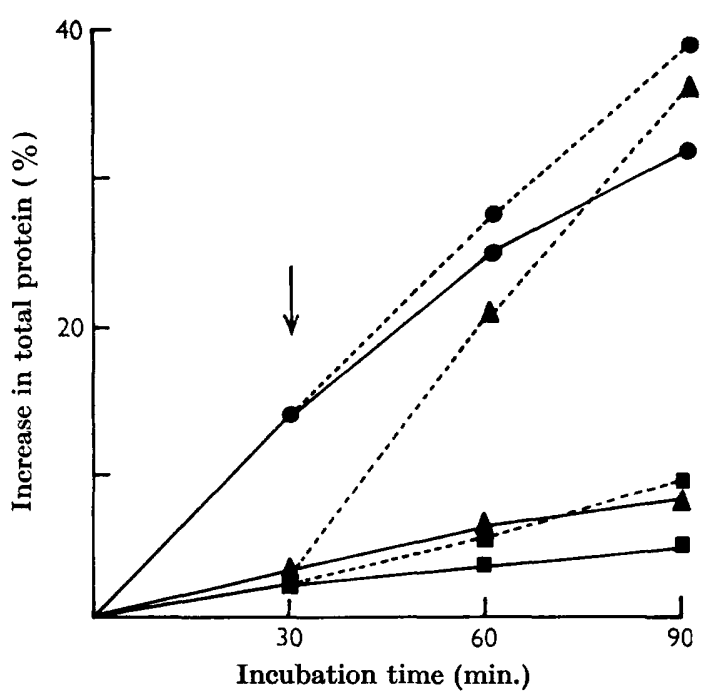

Fig. 3. Net protein synthesis in Staphylococcus aureus after streptogramin or chloramphenicol treatment. Suspensions of $1 \mathrm{mg}$. Staphylococcus aureus/ml. were incubated at $37^{\circ}$ for $90 \mathrm{~min}$. in the defined medium without antibiotic (-O $->$ ), with $30 \mu \mathrm{g}$.

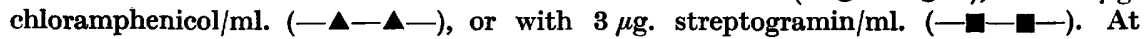
time $30 \mathrm{~min}$. (at arrow) portions of the bacteria were spun down, washed twice and resuspended in fresh medium free from antibiotic. Broken lines show increase in total protein synthesis after resuspending $S$. aureus in fresh medium.

Table 6. The effect of the streptogramin antibiotics on $\left[{ }^{14} \mathrm{C}\right]$ chloramphenicol uptake by Staphylococcus aureus

Antibiotic concentration

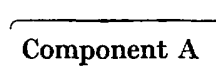

$$
\begin{aligned}
& 1 \times \overline{10^{-6}} \mathrm{M} \\
& 3 \times 10^{-6} \mathrm{M} \\
& 1 \times 10^{-5} \mathrm{M} \\
& 3 \times 10^{-5} \mathrm{M} \\
& 1 \times 10^{-4} \mathrm{M}
\end{aligned}
$$$$
\text { - }
$$$$
-
$$$$
\overline{-}
$$$$
\text { 三 }
$$$$
\left(1 \times 10^{-6} \mathrm{M}+1 \times 10^{-7} \mathrm{M}\right)^{*}
$$

Component $\mathbf{B}$

$$
\begin{gathered}
- \\
- \\
- \\
- \\
- \\
1 \times 10^{-6} \mathrm{M} \\
3 \times 10^{-6} \mathrm{M} \\
1 \times 10^{-5} \mathrm{M} \\
3 \times 10^{-5} \mathrm{M} \\
1 \times 10^{-4} \mathrm{M}
\end{gathered}
$$$$
\left(1 \times 10^{-5} \mathrm{M}+1 \times 10^{-6} \mathrm{M}\right)
$$

\section{$\mu \mu$ moles}

[14C]CAP

taken up,

mg. bacteria

* Minimum growth-inhibitory concentration of the antibiotic(s).

Suspensions of Staphylococcus aureus $\left(0.25 \mathrm{mg} . / \mathrm{ml}\right.$.) in medium A were incubated at $37^{\circ}$ in the presence of $\left(3 \times 10^{-6} \mathrm{M}\right)\left[{ }^{14} \mathrm{C}\right]$ chloramphenicol with the required antibiotic. After $15 \mathrm{~min}$. the bacteria were harvested by centrifugation and the surface of the bacterial pellet rinsed with buffered salt solution. Finally bacteria were resuspended in water, and the radioactivity determined. Corrections were made for $\left[{ }^{14} \mathrm{C}\right]$ chloramphenicol present in the intercellular fluid as previously described (Vazquez, $1965 b$ ). 
$\left[{ }^{14} \mathrm{C}\right] \mathrm{CAP}$. This binding was inhibited by component $\mathrm{A}$ but not by component $\mathrm{B}$. However, the addition of components $\mathbf{A}$ and $\mathbf{B}$ to ribosomes slightly reduced $\left[{ }^{14} \mathrm{C}\right] \mathrm{CAP}$ binding still further. Nevertheless, the effect of component $\mathrm{B}$ was too small to explain the strong synergistic effect of the two streptogramin components on intact cells. Addition of components $\mathbf{A}$ and $\mathrm{B}$ before or after $\left[{ }^{14} \mathrm{C}\right] \mathrm{CAP}$ did not significantly change the results. In further experiments suspensions of Staphylococcus aureus were incubated with streptogramin or mixtures of components $\mathbf{A}$

Table 7. Binding of $\left[{ }^{14} \mathrm{C}\right]$ chloramphenicol to bacterial ribosomes.

Intact bacteria pretreated with the streptogramin antibiotics

\begin{tabular}{|c|c|c|c|c|c|c|}
\hline \multirow[b]{2}{*}{ Organism } & \multicolumn{3}{|c|}{ Conditions of incubation } & \multicolumn{2}{|c|}{ Antibiotic concentration } & \multirow{2}{*}{$\begin{array}{c}\left.{ }^{[4} \mathrm{C}\right] \mathrm{CAl} \\
\text { binding } \\
\text { ( } \% \text { of } \\
\text { control) }\end{array}$} \\
\hline & Medium & $\begin{array}{c}\text { Tem- } \\
\text { perature }\end{array}$ & $\begin{array}{l}\text { Time } \\
\text { (min.) }\end{array}$ & $\begin{array}{c}\text { Component } \\
\text { A }\end{array}$ & $\begin{array}{c}\text { Component } \\
\text { B }\end{array}$ & \\
\hline S. aureus & $\mathbf{A}$ & $37^{\circ}$ & 20 & $\begin{array}{c}1 \times 10^{-6} \mathrm{M} \\
5 \times 10^{-6} \mathrm{M} \\
1 \times 10^{-5} \mathrm{M} \\
3 \times 10^{-5} \mathrm{M} \\
-\overline{10^{-6}} \mathrm{M} \\
1 \times 10^{-6} \mathrm{M}\end{array}$ & $\begin{array}{c}- \\
- \\
\overline{-} \\
5 \times \overline{10^{-7} \mathrm{M}} \\
1 \times 10^{-7} \mathrm{M} \\
5 \times 10^{-7} \mathrm{M}\end{array}$ & $\begin{array}{r}97 \\
78 \\
54 \\
45 \\
100 \\
24 \\
4\end{array}$ \\
\hline & Buffer* & $4^{\circ}$ & 10 & $1 \times 10^{-5} \mathrm{M}$ & - & 50 \\
\hline & A & $4^{\circ}$ & 10 & $1 \times 10^{-5} \mathrm{M}$ & 一 & 56 \\
\hline & A & $37^{\circ}$ & 10 & $1 \times 10^{-5} \mathrm{M}$ & - & 58 \\
\hline & Buffer* & $4^{\circ}$ & 10 & $1 \times 10^{-6} \mathrm{M}$ & $1 \times 10^{-7} \mathrm{M}$ & 88 \\
\hline & A & $4^{\circ}$ & 10 & $1 \times 10^{-6} \mathrm{M}$ & $1 \times 10^{-7} \mathrm{M}$ & 92 \\
\hline & $\mathbf{A}$ & $37^{\circ}$ & 10 & $1 \times 10^{-6} \mathrm{M}$ & $1 \times 10^{-7} \mathrm{M}$ & 38 \\
\hline E. coli & Peptone $\dagger$ & $37^{\circ}$ & 20 & $\begin{array}{l}1 \times{\overline{10^{-5}} \mathrm{M}}^{1 \times 0^{-5}} \mathrm{M}\end{array}$ & $\begin{array}{l}-\overline{0^{-6}} \mathrm{M} \\
2 \times 10^{-6} \mathrm{M}\end{array}$ & $\begin{array}{r}58 \\
100 \\
55\end{array}$ \\
\hline
\end{tabular}

* The buffered salt solution of Gale (1947).

$\dagger$ Medium containing $5 \mathrm{mg}$. Difco Bacto peptone/ml.

Suspensions of bacteria $(3 \mathrm{mg} . / \mathrm{ml}$.) were incubated under the specified conditions. At the end of the incubation period, cells were harvested by centrifugation and the surface of the bacterial pellet rinsed with the buffered salt solution. The bacteria were resuspended in the buffered salt solution, prior to ultrasonic breakage and addition of $\left(3 \times 10^{-6} \mathrm{M}\right)\left[{ }^{14} \mathrm{C}\right]$ chloramphenicol to the cellsap containing the bacterial soluble fraction and ribosome subunits. After $5 \mathrm{~min}$. at $4^{\circ}$ the ribosome subunits were harvested by centrifugation at $150,000 \mathrm{~g}$. for $150 \mathrm{~min}$. and the radioactivity in the pellet estimated. Ribosomes and soluble fraction from $60 \mathrm{mg}$. bacteria were added per tube (2 ml. tubes).

and $\mathrm{B}$, before breakage of the cocci and the addition of $\left.{ }^{[4} \mathrm{C}\right] \mathrm{CAP}$ to the cell sap; the amount of chloramphenicol bound to ribosomes was then markedly decreased (Table 7), and component $B$ enhanced the effect of component $A$ on $\left[{ }^{14} \mathrm{C}\right] \mathrm{CAP}$ binding. Component $\mathbf{A}$ alone was also effective when cocci were incubated at $4^{\circ}$ during the pretreatment with this antibiotic but the additional inhibition due to component B only occurred under conditions where growth would normally occur in the absence of the antibiotics (Table 7). Components A and B had no synergistic inhibitory effect on the growth of Escherichia coli and, in this organism, pre-treatment of intact cells with $A+B$ did not enhance the inhibitory effect of component $A$ in the binding of $\left[{ }^{14} \mathrm{C}\right] \mathrm{CAP}$ to ribosomes.

Since chloramphenicol protects Staphylococcus aureus against the bactericidal 
effect of streptogramin, chloramphenicol might have inhibited the association of streptogramin with ribosomes. This was tested by treating $S$. aureus with a mixture of streptogramin and chloramphenicol before breakage of the cells and treatment of the cell-cap with $\left[{ }^{14} \mathrm{C}\right] \mathrm{CAP}$ (Table 8), but this did not annul the inhibitory effect of

Table 8. Binding of $\left[{ }^{14} \mathrm{C}\right]$ chloramphenicol to Staphylococcus aureus ribosomes after pre-treatment of the bacteria with the streptogramin antibiotics

Antibiotics added during the initial incubation

$$
\begin{aligned}
& \text { Chloramphenicol (3.3 } \mu \mathrm{g} . / \mathrm{ml} .) \\
& \text { Streptogramin (0.6 } \mu \mathrm{g} . / \mathrm{ml} .) \\
& \text { Chloramphenicol and }(3 \cdot 3 \mu \mathrm{g} . / \mathrm{ml} .)+ \\
& \text { streptogramin (0.6 } \mu \mathrm{g} . / \mathrm{ml} .)
\end{aligned}
$$

\author{
$\left[{ }^{14} \mathrm{C}\right]$ chloramphenicol \\ binding \\ ( \% of control)
}

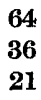

64:

21

Suspensions of Staphylococcus aureus ( $3 \mathrm{mg}$. bacteria/ml.) in medium A were incubated at $37^{\circ}$ for $15 \mathrm{~min}$. in the presence of the required antibiotic(s). At the end of the incubation period, cells were harvested by centrifugation and the experiment continued as described in Table $\gamma$.

Table 9. The effect of the streptogramin antibiotics on the binding of $\left[{ }^{14} \mathrm{C}\right]$ chloramphenicol to Bacillus megaterium ribosomes

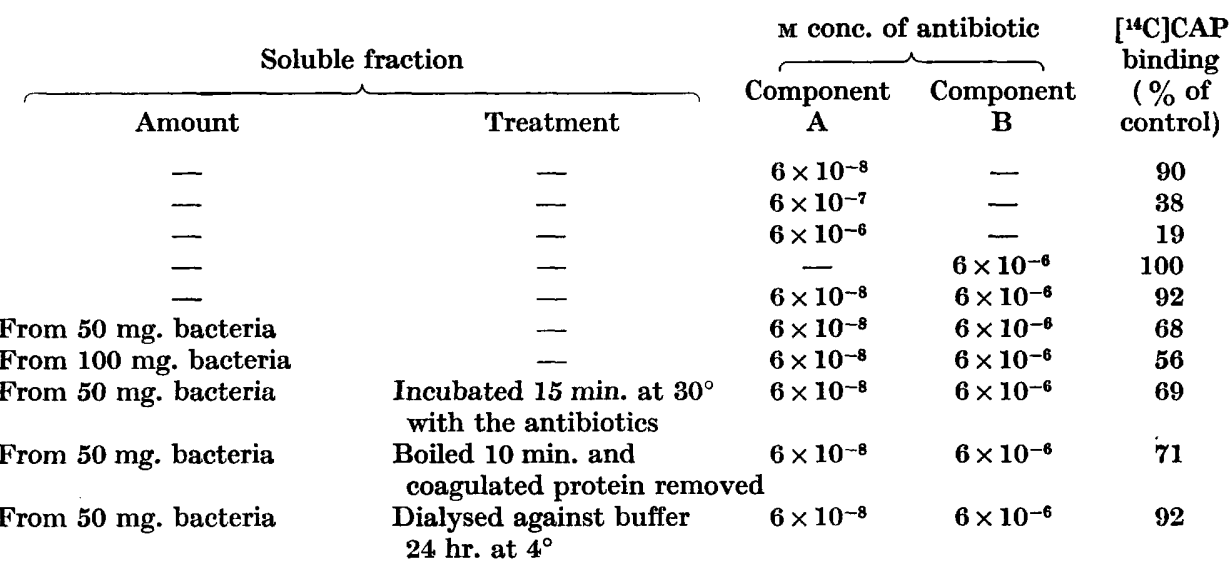

The different experimental conditions set out above produced no alteration in the separate effects of component $A\left(6 \times 10^{-8} \mathrm{M}\right)$ or component $\mathrm{B}\left(6 \times 10^{-6} \mathrm{M}\right)$ on the binding of ${ }^{14} \mathrm{C}$-chloramphenicol.

Ribosome suspensions in $0.01 \mathrm{M}$-tris $+\mathrm{HCl}$ buffer, $\mathrm{pH} 7 \cdot 4$, containing $0.01 \mathrm{M}^{-\mathrm{Mg}^{2+}}$ and $0.2 \mathrm{M}-\mathrm{K}^{+}$ were incubated for $5 \mathrm{~min}$. at $4^{\circ}$ with a mixture of $\left.\left(3 \times 10^{-6} \mathrm{M}\right){ }^{14} \mathrm{C}\right] \mathrm{chloramphenicol}$ and the required antibiotic(s) and the additions as shown in the table. The ribosomes were harvested by centrifugation at $150,000 \mathrm{~g}$ for $100 \mathrm{~min}$. and the radioactivity in the pellet estimated. $2 \mathrm{mg}$. of ribosomes were added per tube ( $2 \mathrm{ml}$. tubes).

streptogramin on the binding of $\left[{ }^{14} \mathrm{C}\right] \mathrm{CAP}$ by ribosomes. Similar results to those found with streptogramin were obtained with the equivalent mixture of components $\mathbf{A}$ and $\mathbf{B}$.

Bacillus megaterium is more easily broken than Staphylococcus aureus, and further studies on the interaction of the streptogramin components have been carried out mainly with ribosomes from $B$. megaterium. The binding of $\left[{ }^{14} \mathrm{C}\right] \mathrm{CAP}$ to bacterial 
ribosomes is not dependent on the presence of the soluble fraction; maximum binding to $70 \mathrm{~S}$ ribosomes occurs in $0.01 \mathrm{M}$-tris $+\mathrm{HCl}$ buffer, $\mathrm{pH} \mathrm{7.4,} \mathrm{containing}$ $0.01 \mathrm{M}-\mathrm{Mg}^{2+}$ and $0.2 \mathrm{M}-\mathrm{K}^{+}$or $\mathrm{NH}_{4}^{+}$(Vazquez, 1964b). The previous finding that component $\mathbf{B}$ enhanced the inhibitory effect of component $\mathbf{A}$ on the binding of $\left[{ }^{14} \mathrm{C}\right] \mathrm{CAP}$ to ribosomes was not confirmed with ribosomes from $\boldsymbol{B}$. megaterium, $E$. coli or $S$. aureus when these were suspended in $0.01 \mathrm{M}$-tris-HCl buffer containing either $0.01 \mathrm{M}-\mathrm{Mg}^{2+}$ and $0.2 \mathrm{M}-\mathrm{K}^{+}\left(70 \mathrm{~S}\right.$ ribosomes) or $0.001 \mathrm{M}-\mathrm{Mg}^{2+}$ and $0.06 \mathrm{M}-\mathrm{K}^{+}$ ( $30 \mathrm{~S}$ and $50 \mathrm{~S}$ ribosome subunits). It was then found that enhancement of inhibition required the presence of the soluble fraction and that its extent depended upon the amount of soluble fraction added (Table 9).

Treatment of components $\mathbf{A}$ and $\mathrm{B}$ with soluble fraction before the addition of ribosomes did not increase the inhibitory effect on $\left[{ }^{14} \mathrm{C}\right] \mathrm{CAP}$ binding and the effect of the soluble fraction is not likely to be due to enzymic modification of either component A or B (Table 9). Removal of protein by boiling and centrifugation did not alter the effect of the supernatant fluid. After dialysis against buffer the non-dialyzable part of the soluble fraction was inactive (Table 9); ashed soluble fraction taken up as chloride or nitrate was inactive.

These results were obtained with ribosomes from Bacillus megaterium and have been confirmed with Escherichia coli ribosomes. Since enhancement can be demonstrated in cell-free systems from $\boldsymbol{E}$. coli, but not with whole organisms, component B may be unable to penetrate the intact cells of Gram-negative bacteria.

\section{DISCUSSION}

These results show that the overall effects of streptogramin components A and chloramphenicol are very similar. The inhibitory effect of component $\mathrm{A}$ on $\left[{ }^{14} \mathrm{C}\right] \mathrm{CAP}$ binding suggests that it acts at the ribosome level.This suggestion is supported by the inhibitory effect of the antibiotic on amino acid incorporation (from aminoacyl-s-RNA into protein) in cell-free systems (Vazquez, 1965c). Inhibition of amino acid incorporation by other antibiotics of group $A$ has also been observed in bacterial cell-free systems by other workers (Yamaguchi \& Tanaka, 1964; Laskin \& May Chan, 1964). However, chloramphenicol has a greater effect on the incorporation of proline and lysine than on the incorporation of phenylalanine, whereas component $\mathbf{A}$ inhibits the incorporation of the three amino acids to a similar extent (Vazquez, 1965c), which suggests that component $\mathbf{A}$ does not attach to ribosomes at precisely the same site as chloramphenicol. If so, the inhibitory effect of component $\mathbf{A}$ on $\left[{ }^{14} \mathrm{C}\right] \mathrm{CAP}$ binding to ribosomes might be due to an allosteric effect.

The site of action of streptogramin component $B$ cannot be deduced from the present results. It has an immediate inhibitory effect on protein synthesis, and a delayed effect on cell wall and nucleic acid synthesis. The inhibitory effect of component B on protein synthesis has been confirmed in cell-free systems (Vazquez, 1965c).

The overall effects of streptogramin, or of equivalent mixtures of component $A$ and component $\mathbf{B}$, are similar to those of component $\mathbf{A}$. There are, however, three important differences: $(a)$ the minimum growth-inhibitory concentration of the mixture for Staphylococcus aureus is $10 \%$ of that of component B alone; (b) component $A$ has an immediate effect on protein synthesis, whereas a lag period of about two minutes is observed before the synergistic mixture exerts its effect; $(c)$ com- 
ponent $\mathbf{A}$ is bacteriostatic, whereas the mixture of components $\mathbf{A}$ and $\mathbf{B}$ is bactericidal. No synergism between component $A$ and component $B$ has been found for inhibition of incorporation of proline, lysine and phenylalanine in cell-free systems directed respectively by polycytidylic, polyadenylic and polyuridylic acids (Vazquez, unpublished data). The above results suggest that the synergism of components $A$ and $B$ can be explained by an enhancement by component $B$ of the binding of component A on ribosomes. A dialysable, low molecular weight, heat stable constituent of the soluble fraction, whose nature is at present unknown, is required for this enhancement.

I wish to express my gratitude to Dr D. Kerridge for valuable criticism and encouragement, to Professor E. F. Gale, F.R.S., for his advice and interest and to my colleagues of the Sub-Department of Chemical Microbiology for their helpful discussions. My thanks are due to The British Council and to The Ramsay Memorial Fellowship Trust for Fellowships and to all the colleagues who provided me with samples of different antibiotics.

\section{REFERENCES}

Anand, N. \& Davis, B. D. (1960). Effect of streptomycin on Escherichia coli. Damage by streptomycin to the cell membrane of $E$. coli. Nature, Lond. 185, 22.

Arai, M., Nakamura, S., Sakagam, Y., Fukuhara, K. \& Yonehara, H. (1956). A new antibiotic, mikamycin. J. Antibiot. (Japan), Ser. A, 9, 193.

Ball, S., Boothroyd, B., Lees, K. A., Raper, A. H. \& Lester Smith, E. (1958). Preparation and properties of an antibiotic complex E 129. Biochem. J. 68, $24 P$.

Bodanszky, M. \& ONDextr, A. (1963). Structures of the vernamycin B group of antibiotics. Antimicrobial Ag. \& Chemother. p. 360.

Benazer, F., Cosar, C., Dubost, M., Julou, L. \& Mancy, D. (1962). Un nouvel antibiotique, la pristinamycine (7293 R.P.). Sem. Hôp. Paris, 38, 13.

Burton, K. (1956). A study of the conditions and mechanisms of the diphenylamine estimation of desoxyribonucleic acid. Biochem. J. 62, 315.

Celmer, W. D. \& Sobin, B. A. (1955/56). The isolation of two synergistic antibiotics from a single fermentation source. Antibiotics Ann. p. 437.

Charney, J., Fisher, W. P., Curran, C., Machlowitz, R. A. \& Tytell, A. A. (1953). Streptogramin, a new antibiotic. Antiobiotics \& Chemother. 3, 1283.

Coleman, V. R., Gunnison, J. B. \& Jawetz, E. (1953). Participation of erythromycin and carbomycin in combined antibiotic action in vitro. Proc. Soc. exp. Biol. Med. 83, 668.

DE Somer, P. \& van DiJck, P. (1955). A preliminary report on antibiotic number 899, a streptogramin-like substance. Antibiotics \& Chemother. 5, 632.

GALE, E. F. (1947). The assimilation of amino acids by bacteria. 1. The passage of certain amino acids across the cell wall and their concentration in the internal environment of Streptococcus faecalis. J. gen. Microbiol. 1, 53.

GaLE, E. F. (1963). Mechanisms of antibiotic action. Pharmacol. Rev. 15, 481.

GaLe, E. F. \& Folkes, J. P. (1953 $a$ ). The assimilation of amino acids by bacteria. 14. Nucleic acid and protein synthesis in Staphylococcus aureus. Biochem. J. 53, 483.

Gale, E. F. \& Folkes, J. P. (1953b). The assimilation of amino acids by bacteria. 15. Actions of antibiotics on nucleic acid and protein synthesis in Staphylococcus aureus. Biochem. J. 53, 493.

Garcia-Mendoza, C. (1965). Studies on the mode of action of etamycin (viridogrisein). Biochim. biophys. Acta, $97,394$.

Garrod, L. P. \& Waterworth, P. M. (1956). Behaviour in vitro of some new antistaphylococeal antibiotics. Brit. med. J. ii, 61. 
HANCOCK, R. (1960). Accumulation of pool amino acids in Staphylococcus aureus following inhibition of protein synthesis. Biochim. biophys. Acta, 37, 47.

Hancock, R. \& PARK, J. T. (1958). Cell wall synthesis by Staphylococcus aureus in the presence of chloramphenicol. Nature, Lond. 181, 1050.

Hurwitz, C. \& Rosano, C. L. (1962). Chloramphenicol sensitive and insensitive phases of the lethal action of streptomycin. J. Bact. 83, 1202.

Jawetz, E., Gunnison, J. B., Bruff, J. B. \& Coleman, V. R. (1952). Studies on antibiotic synergism and antagonism. J. Bact. 64, 29.

Kirby, W. M. M. \& Burnell, J. M. (1954). Effect of combinations of antibiotics on lysis of Staphylococcus aureus by penicillin. J. Bact. 67, 50.

LASkin, A. I. \& MAY Chan, W. (1964). Inhibition by vernamycin A of amino acid incorporation in Escherichia coli cell-free systems. Antimicrobial Ag. \& Chemother. p. 485.

Lester Smith, E. (1963). The ostreogrycins. A family of synergistic antibiotics. Proc. Soc. gen. Microbiol. 33, iii.

Lowry, O. H., Rosebrough, N. J., Farr, A. L. \& Randali, R. J. (1951). Protein measurement with the Folin-phenol reagent. J. biol. Chem. 193, 265.

McQuillen, K. \& Roberts, R. B. (1954). The utilization of acetate for synthesis in Escherichia coli. J. biol. Chem. 207, 81.

Miles, A. A. \& Misra, S. S. (1938). The estimation of the bactericidal power of the blood. J. Hyg., Camb. 38, 732.

Prestidge, L. S. \& Pardee, A. B. (1957). Induction of bacterial lysis by penicillin. J. Bact. 74, 48.

SARIN, P. S. (1962). Structural studies on the antibiotics ostreogrycin A and G. Ph.D. Thesis. Cambridge University.

Umbreit, W. W., BuRRIs, R. H. \& StaUfFer, J. F. (1949). Manometric Techniques and Tissue Metabolism. Minneapolis, U.S.A. Burgess Publishing Co.

Vanderhaeghe, H., Van Dijck, P., Parmentier, G. \& De Somer, P. (1957). Isolation and properties of the components of staphylomycin. Antibiotics \& Chemother. 7, 606.

VAzQUEz, D. (1962). Studies on the mode of action of streptogramin. Biochim. biophys. Acta, $61,849$.

VAZquEz, D. (1963a). The effect of streptogramin and related compounds on Staphylococcus aureus. Proc. Soc. gen. Microbiol. 33, ix.

VAzQUez, D. (1963b). Antibiotics which affect protein synthesis: the uptake of ${ }^{14} \mathrm{C}$ chloramphenicol by bacteria. Biochem. biophys. Res. Commun. 12, 409 .

VAzQuez, D. (1964a). The effect of streptogramin A and $B$ on the binding of ${ }^{14} \mathrm{C}$-labelled chloramphenicol to ribosomes. Proc. Soc. gen. Microbiol. 35, v.

VAZQUEz, D. (1964b). The binding of chloramphenicol by ribosomes from Bacillus megaterium. Biochem. biophys. Res. Commun. 15, 464.

VAzQUEZ, D. (1965 a). A method for the preparation of bacterial $50 \mathrm{~S}$ ribosomal subunits. Biochim. biophys. Acta, 108, 154.

VAzQuez, D. (1965b). Binding of chloramphenicol to ribosomes. The effect of a number of antibiotics. Biochim. biophys. Acta (in the Press).

VAzQUez, D. $(1965 c)$. Antibiotics affecting chloramphenicol uptake by bacteria. Their effect on amino acid incorporation in a cell-free system. Biochim. biophys. Acta (in the Press).

Yamaguchi, H. \& Tanaka, N. (1964). Selective toxicity of mikamycins inhibitors of protein synthesis. Nature, Lond. 201, 409. 